AUSTRALIAN JOURNAL OF BASIC AND
APSN:1991-8178
EISSN: 2309-8414
DOI: $10.22587 /$ ajbas.2017.11.15.1
Journal home page: www.ajbasweb.com

\title{
The R Language in Spatial Analysis of Forest Fragments
}

1Juliana Marchesan, ${ }^{1}$ Elisiane Alba, ${ }^{2}$ Letícia Daiane Pedrali, ${ }^{1}$ Mateus Sabadi Schuh, ${ }^{1}$ José Augusto Spiazzi Favarin, ${ }^{1}$ Tiago Luis Badin, ${ }^{3}$ Rudiney Soares Pereira

${ }^{1}$ Postgraduate in Forestry Sciences, Federal University of Santa Maria, Santa Maria, RS, Brazil.

${ }^{2}$ Polytechnic College, Federal University of Santa Maria, Santa Maria, RS, Brazil.

${ }^{3}$ Department rural engineering, Federal University of Santa Maria, Santa Maria, RS, Brazil.

\section{Address For Correspondence:}

Juliana Marchesan, Federal University of Santa Maria, Postgraduate in Forestry Sciences, Av. Roraima, 1000, Camobi, 97105-900, Santa Maria, RS, Brazil.

E-mail: marchesan.ju@gmail.com

\section{ARTICLE INFO}

Article history:

Received 12 October 2017

Accepted 22 December 2017

Available online 31 December 2017

Keywords:

forest fragmentation, satellite image, $R$ software, Atlantic Forest.

\begin{abstract}
A B S T R A C T
Background: For years the deforestation has caused the fragmentation of the native forest in the different biomes, thus, studies that aim at analyzing the remainders spatially become of great importance. Objective: The objective of the present study was to spatially analyze forest fragmentation in the Arroio Grande hydrographic microbasin, central region of Rio Grande do Sul, Brazil, using the R language. Material and Methods: Images of the Landsat 5 / TM satellite were used for the year of 2010, and Landsat 8 / OLI, for the year 2014, the mapping of the forest fragments was carried out by means of the MaxVer classification, in the software SPRING 5.1.8. In the R software, the number of fragments, the total area, the mean size of fragments, the fragment of larger size and the mean nearest neighbor distance were calculated for the two years of study. For this, we needed the igraph, raster, rgdal and rgeos packages available for R. Results: With the results obtained, it was noted that the microbasin had 2,676.06 ha of forest in 2010, while in 2014 that area increased to 3,262.95 ha. The number of forest fragments increased from 2010 to 2014, which totaled 132 and 209 respectively, while the mean size decreased from 20.27 to 15.61 ha. In 2010 , the mean nearest neighbor distance obtained for the study area was $150.98 \mathrm{~m}$, reducing in 2014, to $118.85 \mathrm{~m}$. Conclusion: Thus, it was concluded that there was regeneration of the native forest in the Arroio Grande microbasin and the $\mathrm{R}$ language was promising and efficient for the analysis of spatial data using orbital images. Thus, the present research presented a method of obtaining metrics of landscape ecology that can be used by the community as an instrument for the management and planning of forest remnants.
\end{abstract}

\section{INTRODUCTION}

For years the deforestation has caused the loss of the native forest in the different biomes. The Atlantic Forest stands out as one of the most threatened biomes in the world due to intense deforestation (Jenkins et al., 2013). At present, $12.5 \%$ of its original area remains, accounting for fragments larger than 3 hectares (Fundação SOS Mata Atlântica, 2015), and it is highly fragmented, with 83\% of fragments smaller than 50 ha (Ribeiro et al., 2009).

Forest fragmentation has several consequences for the environment. Among these, extinction of fauna and flora species, soil erosion and silting of watercourses (Rudolpho et al., 2013), besides causing edge effects, loss of habitat, decrease of biodiversity, isolation of species, invasion of exotic species and decreased pollination (Calegari et al., 2010). In this way, the fragmentation process changes the trophic interactions, the ecosystem processes and the dynamics of populations and communities (Laurence and Vasconcelos, 2009).

Open Access Journal

Published BY AENSI Publication

(C) 2017 AENSI Publisher All rights reserved

This work is licensed under the Creative Commons Attribution International License (CC BY). http://creativecommons.org/licenses/by/4.0/

\section{(c) () Open Access}

To Cite This Article: Juliana Marchesan, Elisiane Alba, Letícia Daiane Pedrali, Mateus Sabadi Schuh, José Augusto Spiazzi Favarin, Tiago Luis Badin, Rudiney Soares Pereira, The R Language in Spatial Analysis of Forest Fragments. Aust. J. Basic \& Appl. Sci., 11(15): 1-7, 2017 
Thus, studies aiming to spatially analyzing forest remnants in order to ascertain their status in a given area, are of great importance to impose management strategies in order to preserve the remaining fragments (Pirovani, 2010). Hence, despite the high rates of deforestation of the Atlantic Forest, it is in the process of natural regeneration, making it necessary to understand its dynamics in order to establish management strategies for biodiversity conservation (Curto et al., 2015).

In this context, landscape ecology metrics are included, which, by means of calculations, quantify the landscape structure, becoming a parameter for the verification of the spatial changes of the landscape (Lang and Blaschke, 2009). According to the authors, these metrics are important because they provide information for the planning, preservation and conservation of natural resources.

In this perspective, several metrics have been used to analyze spatial patterns through the use of geoprocessing and remote sensing tools (Vidolin et al., 2011), opening a new perspective for their application in order to understand the transformations in the landscape (Rocha, 2011). In this way, softwares have been used to analyze the fragmentation of the landscape.

Recently, researchers have been using the $\mathrm{R}$ language to analyze spatial data, since it is considered promising in the area of remote sensing and geoprocessing, because it is free, flexible in the type of data that can be analyzed and allows changes in the available functions (Muenchen, 2011). Due to these characteristics, $\mathrm{R}$ is a complete and extremely powerful programming language (Casajus, 2013). Currently, it presents great capacity to solve varied problems, however, there is still be improved (Verzani, 2011). Since, using this language to analyze forest fragments, spatially for the calculation of landscape ecology metrics, it is incipient to require implementations.

The study area, the Arroio Grande hydrographic microbasin, located in the state of Rio Grande do Sul, Brazil, is characterized by the predominance of agricultural areas and intense deforestation. Longhi-Santos et al. (2015) points out that the southern region of Brazil had an accelerated development process, which resulted in the conversion of forest areas into agricultural ones.

Thus, the area needs a study that aims to analyze the forest fragments in order to define strategies for conservation and / or preservation of remaining forest remnants. Thus, the objective of the present study was to spatially analyze forest fragmentation in the Arroio Grande hydrographic microbasin, central region of Rio Grande do Sul, Brazil, using the R language.

\section{MATERIAL AND METHODS}

\section{Characterization of the study area:}

The study area, the Arroio Grande hydrographic microbasin, covers the municipalities of Agudo and Paraíso do Sul, occupying an area of approximately 8,860 ha. It is located in the central region of the state of Rio Grande do Sul (Figure 1), between the geographic coordinates $29^{\circ} 41^{\prime} 41^{\prime \prime}$ and $29^{\circ} 35^{\prime} 15^{\prime \prime}$ south latitude and $53^{\circ} 17^{\prime} 18^{\prime \prime}$ and $53^{\circ} 09^{\prime} 07^{\prime \prime}$ west longitude.

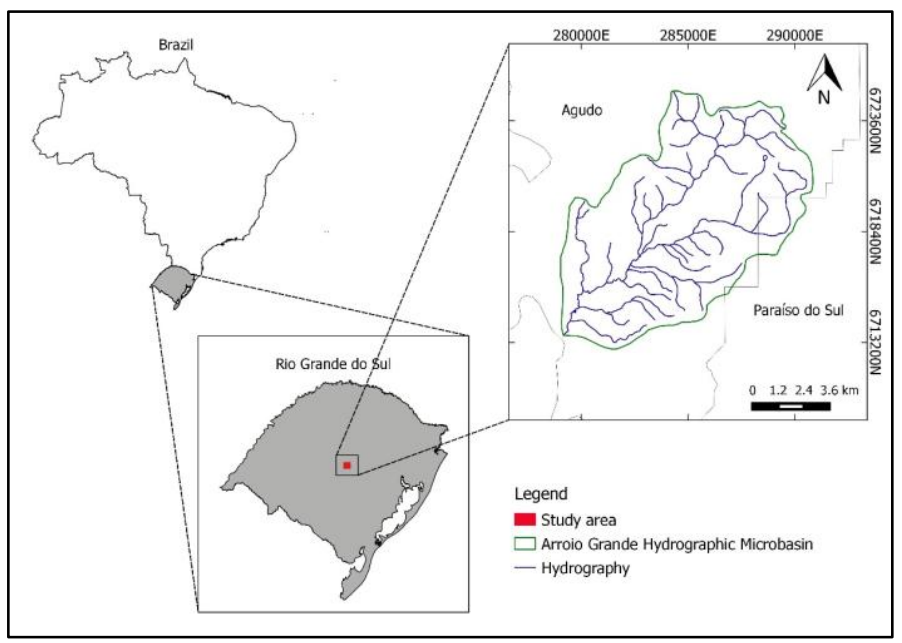

Fig. 1: Location of Arroio Grande hydrographic microbasin, Rio Grande do Sul, Brazil.

According to the classification of Köppen, the climate of the region is humid subtropical (Cfa), with average temperatures varying between $14^{\circ} \mathrm{C}$ and $25^{\circ} \mathrm{C}$, rainfall, in turn, are distributed during the year, with an annual average of 1,700mm (Alvares et al., 2013). The microbasin is positioned in the transition between the Central Depression, constituted of sedimentary rocks of the Paraná Basin, presenting smooth to wavy reliefs, 
and the plateau, formed by volcanic rocks of the Serra Geral formation, that present an approximately tabular relief, much excavated by the rivers (Streck et al., 2008).

The area is occupied by the Atlantic Forest and the economy of the region is centered on agriculture, with the main crop being rice and livestock, with cattle, sheep and pigs (Kobs and Viera, 2010). For decades the native forests have been giving space for the implementation of agriculture and livestock, in this way, it becomes important studies in the region that aim to analyze the forest fragmentation.

\section{Mapping of forest fragments:}

In the SPRING software (Câmara et al., 1996) version 5.2.7 a spatial database was created to import the files of interest. A UTM project with projection (Universal Tranverse Mercator) and the Datum WGS 1984 (World Geodetic System) were created.

The Landsat 5 satellite, Thematic Mapper (TM) sensor, spectral bands 1, 2, 3, 4, 5 and 7, orbit-point 222081, dated 18 / 02/2010, and an image of the Landsat 8 satellite, Operational Land Imager (OLI), consisting of the visible and infrared bands (2, 3, 4, 5, 6 and 7), orbit-point 222-81, dated 28/01/2014, both with spatial resolution of $30 \mathrm{~m}$ and made available free of charge by the United States Geological Survey (USGS), making it possible to analyze spatially the evolution of the fragments during the study period. The images were acquired georeferenced, not being necessary the georeferencing.

At first, the process of manual delimitation of the hydrographic microbasin of study was carried out, in which the curves of level of greater dimension were used as reference. The image processing consisted of band composition tests for later classification that was supervised "pixel by pixel" by means of MaxVer algorithm (Maximum Likelihood).

To evaluate the efficiency of the classification, the Kappa coefficient proposed by Cohen (1960) was used. The results were generated directly in the SPRING application and the table proposed by Landis and Koch (1977) was used to evaluate the quality of the classification (Table 1).

Table 1: Quality of classification according to Kappa coefficient intervals

\begin{tabular}{|c|c|}
\hline Kappa Value & Quality of classification \\
\hline$<0.00$ & Terrible \\
\hline $0.00-0.20$ & Bad \\
\hline $0.20-0.40$ & Reasonable \\
\hline $0.40-0.60$ & Good \\
\hline $0.60-0.80$ & Very good \\
\hline $0.80-1.00$ & Excellent \\
\hline
\end{tabular}

Source: Landis and Koch (1977).

After the mapping of the forest fragments, the raster file was imported into the software $\mathrm{R}$ (R Development Core Team, 2017), using raster packages (Hijmans et al., 2016) version 2.5-8 and rgdal (Bivand et al. , 2016) version 1.2-4. In the $\mathrm{R}$, the total area, in hectares, occupied by the fragments of native forest, the number of fragments, the average size of the fragments in hectares, the largest fragment in hectares, and the average distance of the nearest neighbor, in meters, during the two years of study. For this, we needed the igraph packages (Csardi and Nepusz, 2006) version 1.0.1, raster and rgeos (Bivand and Rundel, 2016) version 0.3-21 available in CRAN (https://cran.r-project.org /).

The functions developed were tested in a known area, in order to verify the veracity of the results. Later, the functions were applied in the study area to analyze the forest fragments in a time interval.

\section{RESULTS AND DISCUSSION}

The Kappa index was $97.00 \%$ and $95.60 \%$ for the years 2010 and 2014 respectively, these were obtained through the own samples acquired in the training by the SPRING, qualifying in an "excellent" classification according to the Table 1. Figure 2 represents the spatial distribution of native forest fragments in the study area.

Visually analyzing the distribution maps of forest fragments in the years 2010 and 2014, it was possible to perceive that forest regeneration in areas south of the watershed were relevant. The same occurred in more sloping areas located in the northern region of the study area.

According to Table 2 it was noted that the microbasin had 2,676.06 ha of forest in 2010, while in 2014 this area increased to 3,262.95 ha. Marchesan et al. (2015) observed a predominance of agriculture and livestock in the study area, which occupied approximately $63 \%$ of the area in 2014, however, it was noticeable the replacement of areas previously occupied by these coverages by areas of native forest, observing its increasing.

The number of fragments increased, from 132 to 209 in 2014, and the mean size of fragments decreased, which in 2010 were 20.27 ha and in 2014 this value was 15.61 ha. This decrease is caused by, among other factors, an increase in the number of small fragments, thus reducing the mean size. 


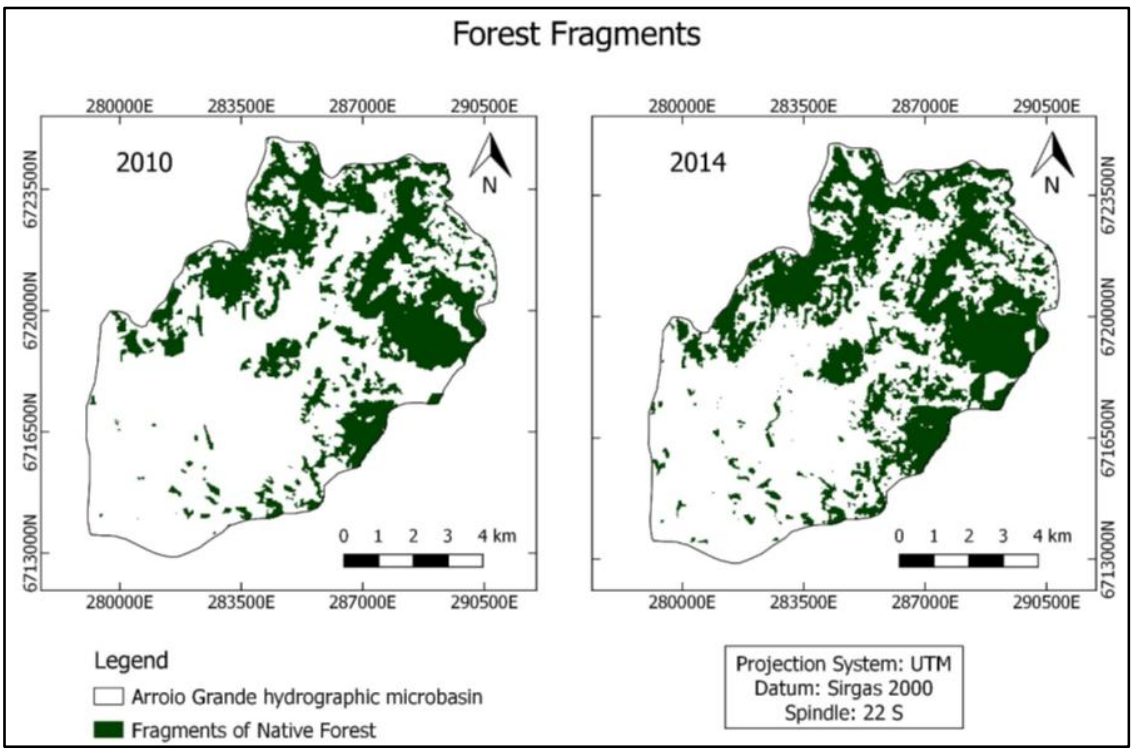

Fig. 2: Map of the forest fragments of the Arroio Grande hydrographic microbasin, Rio Grande do Sul, for the years 2010 and 2014.

Table 2: Values of landscape ecology metrics for forest fragments in the Arroio Grande hydrographic microbasin, Rio Grande do Sul, Brazil, for the years 2010 and 2014.

\begin{tabular}{|c|c|c|}
\hline Landscape Ecology Metrics & 2010 & 2014 \\
\hline Total area of fragments (ha) & $2,676.06$ & $3,262.95$ \\
\hline Number of fragments & 132 & 209 \\
\hline Mean size of fragments (ha) & 20.27 & 15.61 \\
\hline Fragment of larger size (ha) & $1,732.86$ & $2,096.73$ \\
\hline Mean nearest neighbor distance (m) & 150.98 & 118.85 \\
\hline
\end{tabular}

Corroborating with the described, the quantitative results indicate that there was regeneration of native forest areas, since it obtained increase in the area occupied by the class. This fact is related to the rural exodus, recurrent in rural areas today, and the abandonment of areas previously used for agriculture or livestock. In addition, it was noticed an increase in the number of forest fragments, this result also indicates the regeneration of forest areas in the Arroio Grande hydrographic microbasin. The increase in area and number of fragments is best visualized in Figure 3.

Relationship between total area and the number of fragments

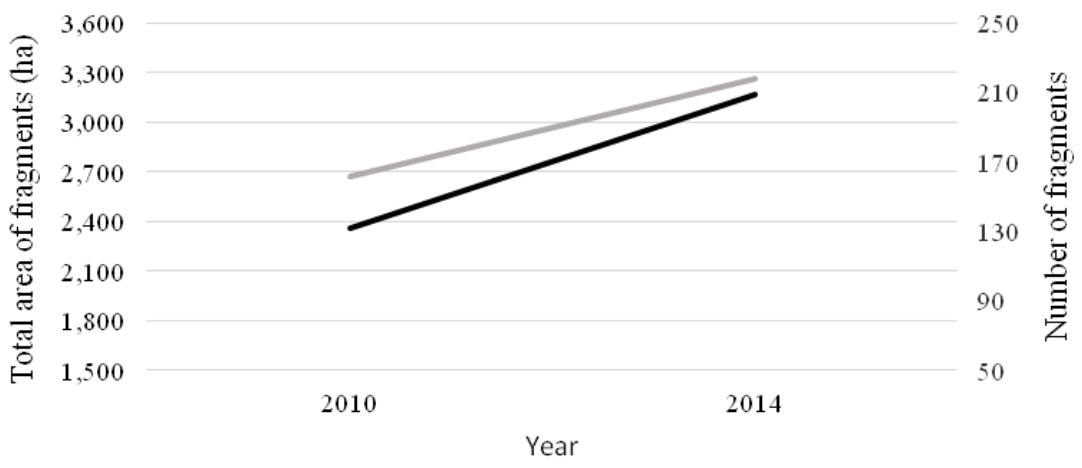

Total area of fragments (ha) _ Number of fragments

Fig. 3: Relation between the total area (ha) and the number of fragments in the Arroio Grande hydrographic microbasin, Rio Grande do Sul, Brazil, between 2010 and 2014.

The largest fragment increased from 2010 to 2014 covering 2,096.73 ha in the last year. This fragment is located in the upper region of the microbasin, where there are areas with larger slopes, and it is possible to notice that in these places the forest remnants are more preserved (Marchesan et al., 2015), located in areas with 
high slopes or in the tops of hills, that is, in places unsuitable for agricultural crops. Large fragments present an important ecological role, because they harbor greater diversity of both fauna and flora (Veronese, 2009).

In the lowland areas, located to the south of the microbasin, few fragments are found, and when they exist, they present small areas. Zanella (2011) reports that fragments of smaller sizes are important in the landscape, since they reduce the isolation of larger fragments, which are usually more isolated. However, fragments with reduced sizes are poor in diversity (Veronese, 2009).

The isolation of the fragments, in turn, is determined by the mean nearest neighbor distance metric (Almeida, 2008). This metric is important, since it indicates the degree of isolation of the landscape and, consequently, the necessity of implantation or existence of connection elements, such as ecological corridors (Vidolin et al., 2011). In 2010, the average distance of the nearest neighbor obtained for the study area was $150.98 \mathrm{~m}$, reducing in 2014, to $118.85 \mathrm{~m}$. The same trend of distance reduction was obtained by Pirovani et al. (2015) in a study in the vicinity of the RPPN CAFUNDÓ, Espírito Santo, in which the authors point out that this decrease may not indicate an improvement in conservation, since it may point to an increase in fragmentation.

Cemin et al. (2009) when analyzing the distance of the nearest neighbor in deciduous forest areas, in the Taquari Valley, Rio Grande do Sul, found a mean distance of $59.62 \mathrm{~m}$, lower values than those obtained in the present study, a similar result was obtained by Almeida (2008), with approximately $56 \mathrm{~m}$ of distance in the Atlantic Forest area of Paraná and by Périco and Cemin (2006) in a study in the municipality of Arvorezinha, Rio Grande do Sul, with a distance of $66.09 \mathrm{~m}$. Thus, it is noticeable that in the Arroio Grande hydrographic microbasin the distance between the fragments is high when compared to other authors, this is due to the large extensions of agricultural and livestock areas, existing in the microbasin, without the presence of forest fragments.

The distances between fragments have several consequences for both fauna and flora. In this context, fragments that are located distant from each other tend to undergo changes in their composition both vegetal and animal over the years. Cerqueira et al. (2003) shows that in isolated fragments the rate of migration and dispersion becomes smaller and, over time, they suffer problems of gene exchange and population decrease.

According to Zanella (2011), the distance can be considered a barrier for several species that do not have the ability to cross matrices of great distances. Analyzing the remnants present in the study area, it was possible to perceive that the fragments are distant from each other, which in the course of the years will lead to fragments with less diversity of species. Silva and Souza (2014) complement that isolation reduces biological diversity, as well as immigration rates, thus, the higher the degree of fragmentation, the higher the risks of establishment exotic species, further accelerating the loss of biodiversity.

\section{Conclusions:}

The $\mathrm{R}$ language was promising and efficient for the analysis of spatial data using orbital images. Thus, with this work it was possible to demonstrate one of the several utilities of the tool, allowing to encourage future works that use the same one.

Regarding the native forest fragments present in the study area, the Arroio Grande hydrographic microbasin, an increase was observed from 2010 to 2014, indicating the regeneration of areas formerly occupied by agriculture or livestock. In addition, there was an increase in the number of fragments and a decrease in the distance between them, being another indication of the regeneration of forest areas.

In this way, the research presented a method to obtain landscape ecology metrics that could be used by the community as an instrument for the management and planning of forest remnants, since free images and tools were used. Thus, the present study will assist in landscape ecology research and public policies aimed at the conservation, preservation and recovery of forest areas, establishing measures to increase connectivity with the creation of ecological corridors.

\section{REFERENCES}

Almeida, C.G., 2008. Análise espacial dos fragmentos florestais na área do Parque Nacional dos Campos Gerias, Paraná. M.S. thesis, Universidade Estadual de Ponta Grossa, Ponta Grossa, Paraná, Brasil.

Alvares, C.A., J.L. Stape, P.C. Sentelhas, J.L.M. Gonçalves, G. Sparovek, 2013. Köppen climate classification map for Brazil. Meteorologische Zeitschrift, 22 (6): 711-728.

Bivand, R., C. Rundel, 2016. rgeos: Interface to Geometry Engine - Open Source (GEOS). R package, v. 0.3-21. <https://CRAN.R-project.org/package=rgeos>.

Bivand, R.S., T. Keitt, B. Rowlingson, 2016. rgdal: Bindings for the Geospatial Data Abstraction Library. R package v. 1.2-4. <https://CRAN.R-project.org/package=rgdal>.

Calegari, L., S.V. Martins, J.M. Gleriani, E. Silva and L.C. Busato, 2010. Análise da dinâmica de fragmentos florestais no município de Carandái, MG, para fins de restauração florestal. Revista Árvore, 34(5): 871-880. 
Câmara, G., R.C.M. Souza, U.M. Freitas, J. Garrido, F. II Mitsuo, 1996. SPRING: Integrating remote sensing and GIS by object-oriented data modelling. Computers \& Graphics, 20(3): 395-403.

Casajus, N., 2013. Analyses spatiales sous R. Uiversité du Québec à Rimouski, Département de Biologie, Chimie et Géographie.

Cemin, G., E. Perico, C. Rampel, 2009. Composição e configuração da paisagem da sub-bacia do Arroio Jacaré, Vale do Taquari, RS, com ênfase nas áreas de florestas. Revista Árvore, 33(4): 705-711.

Cerqueira, R., A. Brant, M.T. Nascimento, R. Pardini, 2003. Fragmentação: Alguns conceitos. In: Rambali, D.M., Oliveira, D.A.S. de. (Org.). Fragmentação de ecossistemas: Causas, efeitos sobre a biodiversidade e recomendações de políticas públicas. Brasília: MMA/SBF, pp: 23-40.

Cohen, J.A., 1960. Coefficient of agreement for nominal scales. Educational and Measurement, 20(1): 3746.

Csardi G., T. Nepusz, 2006. The igraph software package for complex network research. InterJournal, Complex Systems 1695. <http://igraph.org>.

Curto, R.A., G.F. Silva, R. Môra, R.O.V. Miranda, A.P.D. Fernandes, E.J.G. Araújo, 2015. Structure of the arboreal component of a Semideciduous Seasonal Forest in the south of Espirito Santo state, Brazil. Australian Journal of Basic and Applied Sciences, 9(20): 176-186.

Fundação SOS Mata Atlântica., 2015. Relatório Anual 2015. <https://www.sosma.org.br/projeto/atlas-damata-atlantica/dados-mais-recentes/>.

Hijmans, R.J., J.V. Etten, J. Cheng, M. Mattiuzzi, M. Sumner, J.A. Greenberg, O.P. Lamigueiro, A. Bevan, E.B. Racine, A. Shortridge, 2016. raster: Geographic Data Analysis and Modeling. R package v. 2.5-8. $<$ https://CRAN.R-project.org/package=raster $>$.

Jenkins, C.N., S.L. Pimm, L.N. Joppa, 2013. Global patterns of terrestrial vertebrate diversity and conservation. PNAS, 110(28): 1-9.

Kobs, M., V. Viera, 2010. Degradação ambiental do Arroio Grande (Hermes) na cidade de Agudo, RS. Revista Disciplinarum Scientia. Série: Ciências Humanas, Santa Maria, 11(1): 17-27.

Landis, J.R., G.G. Koch, 1977. The measurement of observer agreement for categorical data. Biometrics, 33(1): 159-174.

Lang, S., T. Blaschke, 2009. Análise da paisagem com SIG. Kux, H. [trad.]. São Paulo: Oficina de Textos, pp: 424.

Laurence, W.F., H.L. Vasconcelos, 2009. Consequências ecológicas da fragmentação florestal na Amazônia. Oecologia Brasiliensis, 13: 343-451.

Longhi-Santos, T., J.E.F Milani, B.P. Miranda, V.H.F. Andrade, F. Galvão, M.R. Kanieski, C.V. Roderjan, 2015. Australian Journal of Basic and Applied Sciences, 9(20): 20-26.

Marchesan, J., L.D. Pedrali, E. Alba, J. Tramontina, R.S. Pereira, 2015. Influência de características físicas nas mudanças de uso e cobertura da terra na microbacia hidrográfica do Arroio Grande - RS. In: I Simpósio Internacional de águas, solos e geotecnologias, Uberaba, pp: 1-11.

Muenchen, R.A., 2011. R for SAS and SPSS Users. Nova York: Springer, pp: 685.

Périco, E., G. Cemin, 2006. Caracterização da paisagem do município de Arvorezinha, RS, com ênfase na dinâmica dos fragmentos florestais, por meio de sistemas de informações geográficas (SIGs). Scientia Forestalis, 70: 09-21.

Pirovani, D.B., 2010. Fragmentação florestal, dinâmica e ecologia da paisagem na bacia hidrográfica do Rio Itapemirim, ES. M.S. thesis, Universidade Federal do Espírito Santo, Jerônimo Monteiro, Espírito Santo, Brasil.

Pirovani, D.B., Silva, A.G.da., Santos, A.R.dos., 2015. Análise da paisagem e mudanças no uso da terra no entorno da RPPN Cafundó, ES. Cerne, 21(1): 27-35.

Development Core Team., R., 2017. R: A Language and Environment for Statistical Computing. Vienna: R Foundation for Statistical Computing. Available online at: 〈http://www.R-project.org/>.

Ribeiro, M.C., J.P. Metzger, A.C. Martensen, F.J. Ponzoni, M.M. Hirota, 2009. The Brazilian Atlantic Forest: How much is left, and how is the remaining forest distributed: Implications for conservation. Biological Conservation, 142(6): 1141-1153.

Rocha, J.G., 2011. Modelagem de conhecimento e métricas de paisagem para identificar e analisar padrões espaciais em ambientes de Caatinga. M.S. thesis, Universidade Federal de Pernambuco, Recife, Pernambuco, Brasil.

Rudolpho, L.S., G. Braghirolli, J.C. Refosco, A.G. Santiago, R.T. Saboya, 2013. Aplicação de técnicas de geoprocessamento e métricas da paisagem na análise temporal da cobertura florestal da Bacia do Ribeirão Fortaleza em Blumenau/SC. In: XVI Simpósio Brasileiro De Sensoriamento Remoto, Foz do Iguaçu: INPE, pp: 1742-1749.

Silva, M.S.F.da. and R.M. Souza, , 2014. Padrões espaciais de fragmentação florestal na Flona do Ibura Sergipe. Mercator, 13(3): 121-137.

Streck, E.V., N. Kämpf, R.S.D. Dalmolin, E. Klamt, P.C. Nascimento, P. Schneider, E. Giasson, L.F.S. Pinto, 2008. Solos do Rio Grande do Sul. Porto Alegre: EMATER-RS/UFRGS, pp: 22. 
Verzani, J., 2011. Getting started wich RStudio. Sebastopol: O’Reilly Media, pp: 92.

Veronese, J.V., 2009. Análise de fragmentos florestais e proposição de corredores ecológicos com base no Código Florestal - Lei 4.771/65: aplicação na Serra do Brigadeiro - MG. Specialization in environmental analysis, Universidade Federal de Juiz de Fora, Juiz de Fora, Brasil.

Vidolin, G.P., D. Biondi, A. Wandembruck, 2011. Análise da estrutura da paisagem de um remanescente de floresta com araucária, Paraná, Brasil. Revista Árvore, 35(3): 515-525.

Zanella, L., 2011. Análise da interferência antrópica na fragmentação da Mata Atlântica e modelos de simulação da paisagem na microrregião da Serra da Mantiqueira do estado de Minas Gerais. Thesis (Master), Universidade Federal de Lavras, Minas Gerais, Brasil, 2011. 